\title{
Spousal resources and relationship quality \\ in eight European countries
}

Maike van Damme \& Pearl Dykstra

To cite this article: Maike van Damme \& Pearl Dykstra (2018) Spousal resources and

relationship quality in eight European countries, Community, Work \& Family, 21:5, 541-563,

DOI: $10.1080 / 13668803.2018 .1526776$

To link to this article: https://doi.org/10.1080/13668803.2018.1526776

\begin{abstract}
We relate relationship satisfaction and thoughts about leaving a romantic relationship to a couple's relative and absolute resources and check for context-dependency of those associations. Our theoretical point of departure is that the more resources women have compared to their spouses, the higher their intra-household bargaining power to negotiate themselves out of unpleasant tasks, particularly in gender-egalitarian and very income equal and unequal societies. In traditional societies (which score low on the Gender Empowerment Measure (GEM)), the inflexible role of men within the household presumably prevents women from bargaining a better position, which in turn negatively affects relationship quality. Income equality (low GINI coefficient) may be a prerequisite for women's bargaining position, where more inequality (mid-GINI) may be detrimental for it. Nevertheless, extreme income inequality (high GINI) may again be favorable for women's relationship power. Using country fixed effects models on data from the Generations and Gender Surveys (GGS), we compare men and women who are in a couple (formed after 1995) for eight European countries. We find that absolute resources matter more than relative resources, at least for relationship satisfaction: Higher educated couples are more satisfied with their relationships, which could suggest lower stress levels in those couples (in more traditional contexts). Second, we observe GINI contextdependency of the association between relative education and relationship satisfaction for
\end{abstract}


women and relative education and exit thoughts for men, although opposite to what we expected. Perhaps reference group theory or gender display theory can explain these unexpected results. Finally, we find that women have more break-up plans in societies with a lower score on GEM. This last result is consistent with the notion that bargaining only works in egalitarian contexts. 


\section{Introduction: broadening our perspective on the impact of resources}

Whether one evaluates the increasing divorce trend of the last decades in a positive or negative way, investigating this topic is of importance both for policymakers and scholars alike. Relative resource theory provides one possible explanation for higher divorce rates. Having more resources compared to one's spouse may increase one's bargaining position within the household and may have consequences for the quality of one's relationship. In this paper, we do not examine divorce itself, but use two alternative measures of relationship quality: relationship (dis)satisfaction and whether individuals think about breaking up. These subjective measures are correlated with actual divorce (Karney \& Bradbury, 1995) and more importantly, they are stages in the complex process of divorce. When investigating causes of divorce, it is important to examine the onset of the process of divorce.

Using the first wave of the Generations and Gender Survey (GGS) ${ }^{1}$, we examine the correlates of resources with relationship satisfaction and thoughts of divorce in eight European countries for both men and women. We contribute to the previous literature in three areas: First, we not only consider earnings as resources, but also educational level and occupational status. Each of these three types of resources can give a spouse bargaining power within the relationship (e.g. Rodman, 1967; Ruppanner, 2010). Second, we not only consider the relative level but also the absolute level of spousal resources. Not controlling for absolute levels may bias the associations between relative resources and marital quality (van Berkel, 1998). Relative resources are actually a measure of symmetry within the couple, rather than economic independence, which is what absolute resources represent. For instance, a woman whose spouse is a millionaire could earn $20 \%$ of his income, whereas a woman whose spouse receives minimum income payments 
could earn $100 \%$ of his income. Even though the latter woman earns symmetrically the same as her spouse, it is likely that she is more dependent on his income. The absolute independence of this woman is still rather low should a separation occur. In that case, she would have to rely on other sources of income such as the state, family, or the ex-spouse (McKeever \& Wolfinger, 2001; van Damme, 2010). Oppenheimer (1997) argues the same point. Criticizing Becker's specialization model empirically and theoretically, she stressed that looking at relative resources is not enough and does not provide any information about the actual independence of women in a relationship. A third area of advance is that we extend previous research in a cross-national way by moderating the association between resources and relationship quality by context. We replicate studies on spousal resources and relationship quality for eight European countries in addition to giving an explanation for within-country differences in the effects of relative and absolute resources by referring to the level of gender egalitarianism in a society (measured by the Gender Empowerment Measure (GEM)) and the extent of income inequality (using the GINI coefficient of each country year). We chose both Western and Eastern European countries to analyze because we would like to see effects of bargaining and absolute resources on relationship quality in highly varying contexts. Next to Belgium and France, where an increase in GEM scores has been taking place around the millennium, we include more traditional (Georgia, Russia, Romania, Bulgaria) and more egalitarian (Czech Republic, Lithuania) Eastern-European contexts. Unfortunately, we could not include very egalitarian societies like Sweden or Norway because of lack of data on either the dependent or one of the main independent variables. But with this country selection, we believe to have a good context variation on both the GEM and GINI measures.

\section{Previous findings on resources and relationship quality}




\section{Relative resources}

Research on relative resources and relationship quality is rather scarce (though there is a plethora of studies on relative resources and divorce). Scholars have investigated different societies: First, findings for the US have been mixed, varying from insignificant effects in old studies (Huber \& Spitze, 1980)2 , positive effects for men (Brennan, Barnett, \& Gareis, 2001) or for women (Rogers \& DeBoer, 2001) in more recent ones (a relatively higher salary is associated with more marital satisfaction), and negative effects on relationship satisfaction and positive effects on 'the marriage is in trouble'-thought in the newest study we found (Bertrand, Kamenica, \& Pan, 2015). This last finding is in line with that which Vannoy and Cubbins (2001) observed for the city of Moscow and Zhang et al. (2012) for urban China: A negative effect of wife's relative income on women's marital satisfaction and a null-effect for men.

Regarding education, Tynes (1990) found that higher relative education for women is associated with more marital satisfaction for both spouses, compared to couples in which men are more highly educated than their wives. Eeckhaut et al. (2013), on the contrary, found with Dutch data that higher relative education for her is related to lower marital satisfaction for men (they did not study women). Gong (2007) found the same for the US, but then for women's marital happiness, and this is especially the case for women with traditional gender ideologies.

The same study (Gong, 2007) reported effects of status inconsistencies between the spouses (wife's occupational status exceeds her husband's) and lower marital happiness of traditional wives. Vannoy and Cubbins (2001) found that Moscow wives' marital quality is not lower when her occupation rank exceeds that of his compared to couples where both have a manager/professional position, nor compared to couples in which she has a lower occupational rank than he has. 


\section{Absolute resources}

When it comes to absolute earnings and relationship quality, Brennan et al. (2001) examined young men of dual earner couples and found greater relationship satisfaction in couples with higher absolute salary, whereas Rogers and DeBoer (2001) found a nonsignificant effect for men and a positive association for women. In the same year, Vannoy and Cubbins (2001) checked for individual effects of average monthly income of the wife and the husband, but did not find any significant effects. A German study found similar insignificant effects of household income on both German men's and women's relationship satisfaction (Hardie, Geist, \& Lucas, 2014), but also an unexpected association between male-breadwinner couples and his relationship satisfaction, which was lower the more a couple adhered towards a male-breadwinner model. The most recent US study on the effects of absolute resources and relationship quality was conducted by Betrand et al. (2015), who controlled the effects of relative income for absolute incomes of the spouses, but did not specify what the absolute income effects were.

Regarding absolute levels of education, Wiik, Lappegård, and Keizer (2010) reported a positive association with relationship satisfaction and having plans to break up in selected European countries. The authors did not relate context-differences in the educational effect to a macro-level indicator (like gender egalitarianism). Similar positive effects of wife's and husband's educational level on marital quality of both men and women were found by Vannoy and Cubbins (2001). Other studies, however, did not find significant educational differences in marital satisfaction (Boertien \& Härkönen, 2018 for the UK; Nock, 1995 for the US), or found opposite effects (higher educated women and 
men have lower marital satisfaction in the Netherlands (Van den Troost, Vermulst, Gerris, Matthijs, \& Welkenhuysen-Gybels, 2006).

When it comes to occupational status effects on relationship satisfaction, we found only one study, which found that lower occupational status couples are less satisfied with their marriages than couples that are both in a managerial/professional position (Vannoy \& Cubbins, 2001).

\section{Theories and hypotheses on the impact of resources}

The sociological (e.g. Blood \& Wolfe, 1960) and economic perspective (e.g. Lundberg \& Pollak, 1996) of bargaining theories both predict similar outcomes concerning the consequences of having more intra-household resources. Those with the most resources are assumed better able to negotiate themselves out of unpleasant tasks, such as domestic work (note that these theories assume that preference/taste for domestic work is low). More specifically, more resources provide a spouse with greater marital power, thereby giving the spouse greater ability to exchange for what (s)he prefers. Spouses who are more dependent on the other in the relationship are less able to bargain for a better situation.

Power is also influenced by a spouses' fallback position (absolute resources), ${ }^{3}$ i.e., the hypothetical position below which each spouse would fall after a separation. Spouses would not be willing to go below a certain level of earnings or standard of living, as this would represent a significant deterioration of their position compared to the position that they currently enjoy in the union. Therefore, absolute resources matter in addition to

relative resources: the more absolute resources a spouse has, the better the fallback 
position and the more influence this person has in decision-making. Because wives' investments (child care and domestic work) are less transferable outside the union and more relationship-specific, wives have fewer alternatives out of the union and therefore less power within the union (England \& Kilbourne, 1990). Just like the previous authors, Hobson (1990) adds to this that Hirschman's (1970) classic study on exit, voice, and loyalty can be applied to couple's marital power. Hobson derives that women in the household can either be loyal (and don't question the division of labour within the household), or use their voice and they will do so more when having more resources. They can also 'vote with their feet' in a situation when they do not agree on the intrahousehold division of labour: i.e. exit the relationship. The less resources women have though, the fewer their exit possibilities. And the fewer exit possibilities, the weaker the voice women have. Indeed, Lennon and Rosenfield (1994) have shown that women who have more absolute resources (i.e., a lower post-divorce poverty potential) and have a better overall position to fall back on outside of the relationship (not only with respect to standard of living, but also regarding social life and career opportunities) more often viewed a given division of labor as unfair. In addition, they found that women who experienced an inequitable situation as unfair had decreased psychological well-being. These considerations have at least two implications for our expectations: First, we expect that women with more relative resources are less satisfied with their relationships $(\mathrm{Hla})$. This may be due to the fact that women are less satisfied with the division of household labor when they get more bargaining power; Second, women with more relative resources are more likely to consider leaving the relationship $(\mathrm{H} 2 a)$ because they have a better fallback position. See Table 1 for a summary of the hypotheses.

For men, we also expect to find an association between her comparative resources and his relationship quality. In couples in which the woman has more resources than the 
man, the traditional division of labor is violated (Brines, 1994; Tichenor, 2005; West \& Zimmerman, 1987). The male spouse does little domestic labor unless both he and his wife hold egalitarian beliefs about gender and marital roles (Greenstein, 1996b). It has also been suggested that breadwinner wives and dependent husbands continue to 'do gender' in order to compensate for violation of a traditional division of labor within the household (Brines, 1994; Tichenor, 2005). In such cases, men in couples with breadwinner wives do not take greater responsibility for the housework to compensate for their wives' contribution, but women would do a 'second shift' of domestic work (Hochschild \& Machung, 1989), with the division of domestic work being equal at best (Cooke, 2006). A violation of the traditional division of labor may lead to conflict, which in turn may cause the man to be less satisfied with the relationship and more likely to think about leaving the relationship. This is a cross-partner effect: her relative resources negatively affect his satisfaction (H1b) or positively affect his thoughts of leaving the relationship $(\mathrm{H} 2 \mathrm{~b})$. Additionally, it might be that for men there is an association between women's relative resources and his marital dissatisfaction via her dissatisfaction. By expressing her discontent with the relation, his feelings of satisfaction will be affected, creating a spill-over effect (Pouwels, 2011). Lacking couple data, we cannot test this spillover effect, but we can still observe the outcome of this mechanism.

In addition, absolute levels of resources are likely to matter. We have two types of expectations about the association between a couples' absolute level of resources and relationship quality. On the one hand, as mentioned above, having more resources of their own would increase women's fall-back position (England \& Kilbourne, 1990; Lennon \& Rosenfeld, 1994), providing them greater economic independence in the event of a breakup (Oppenheimer, 1997) and would affect relationship satisfaction negatively (H3a for women; H3b for men) and exit thoughts positively (H4a for women; H4b for men). On 
the other hand, more resources in the household (in contrast to the individual) go together with less family stress and better relationship quality (Conger \& Elder, 1994; Oppenheimer, 1997) which increases relationship satisfaction (H5a for women; H5b for men) and reduces break-up thoughts (H6a for women; H6b for men).

Note that selection into a co-residential relationship may also play a role in explaining the association between resources and relationship quality: For example, even today in the Dutch context, high-resource men are more and high-resource women are less likely to form a partnership (Dykstra \& Poortman, 2010). This might imply that those couples, where women have more resources (than men) are also more likely to break up and have a lower relationship satisfaction (as being single is more attractive for them). Hence, we would observe only those couples with relatively good relationship quality among the ones with many female resources as those with bad quality relationships have selected themselves out. With cross-sectional data we cannot estimate the selection effect so one has to keep in mind that we might overestimate the association between relative resources and relationship quality.

\section{Relative resources and context specificity}

England and Kilbourne (1990) argued a couple of decades ago that there are two main things that women would like to change in their marriages: the degree of men's emotional intimacy and the degree of men's participation in domestic work. In addition, EspingAndersen and Billari (2015) emphasized that certain macro-trends seem very hard to change: The traditional male breadwinner family would continue to stay for a long time and men would resist to take up 'women's work' because it would be stigmatizing (see also Brines, 1994; Hobson, 1990). This would especially apply to inegalitarian contexts. The more people adhere to inegalitarian norms and the more stubborn gender role 
patterns, the less women can use their marital power to bargain for a more equal domestic work division ${ }^{4}$. As long as the society remains traditional on average (a certain critical mass within society does not take over more gender-egalitarian values (Esping-Andersen \& Billari, 2015)), relative resources will not translate into marital power and exit would be the only option for women if they want to change an unequal marital situation. From this, we can derive the expectation that the negative influence of relative resources on break-up thoughts will be weaker among women in egalitarian countries than in inegalitarian contexts (H2a_norms). We expect a similar context dependency for marital satisfaction in egalitarian societies (and therefore predict an opposite association): Women with more resources compared to their partners will be happier with their marriages the more egalitarian a society is (H1a_norms). The reason for this would be that women living in egalitarian contexts could bargain a better position within the relationship while they would fail to do so in a traditional environment in which division of labor patterns are more persistent (see also Hajdu and Hajdu (2018)).

For men, we expect cross-partner and spill-over effects. Equity within the household is expected to lead to more happiness in egalitarian societies, not only for her but also for him (a spill-over effect). However, a cross-partner effect could also exist: Her relative resources directly influence his satisfaction and exit thoughts, with him being happier (H1b_norms) and thinking less about breaking up (H2b_norms) when there is more equity within the relationship and less intra-household conflict.

In addition to context differences in gender role norms, class (in)equality could play a role. In unequal contexts with a high GINI coefficient, bargaining could be working less compared to equal contexts where the GINI is low. Based on a study of Hobson (1990), we actually expect a curvilinear relationship between women's economic dependency within the household and the GINI. In Figure 1 of her study (p.241), Hobson 
points out that due to the limited labour force participation of women in relatively income equal countries like Germany and the Netherlands, women's dependency is far higher than in an unequal country like the US. Sweden lies at the other spectrum of inequality (low) and women's dependency within the household (also low). Hobson describes a weak relationship between GINI and women's relative dependency, but the scatterplot hints to a curvilinear relationship with women having better bargaining positions in the most equal (e.g. state encouraged dual earner society Sweden) and most unequal contexts (e.g. market forced dual earner society US). We will therefore include both the GINI and GINI squared to check to what extent a mid-income inequality context goes together with less bargaining in the household when women have more resources and thus less relationship satisfaction (H1a_inequality) and more exit thoughts (H2a_inequality) and whether these associations become more positive in both more income-equal (lowest GINI) and more income-unequal contexts (highest GINI). We expect a similar context moderation effect for men's relationship satisfaction (H1b_inequality) and break up plans (H2b_inequality).

[Table 1 about here]

\section{Data, method, and operationalization}

Data

To investigate the extent to which relative and absolute resources are associated with relationship quality in different contexts, we use the Generations and Gender Survey (GGS). The first wave of this survey was conducted in 19 countries. The sample size is 65,081 when selecting the eight countries that had responses on the two dependent variables and resources. These countries are Belgium, Bulgaria, Czech Republic, France, 
Georgia, Lithuania, Romania, and Russia. The unit of analysis is the individual (aged 1865 years) within a couple who lives with a partner in the same household (and (s)he is not enrolled in education as a main activity). Around one third of the persons are not in a couple and therefore dropped, thereby reducing the sample to 44,697. Note that we do not have couple data, but only observe one of the two partners (see the section on analytical approach for the final sample size).

\section{Measures}

We analyze two outcomes: 1) the amount of satisfaction with the relationship, using the question: 'How satisfied are you with your relationship?'. This indicator of relationship quality has categories ranging from 0 (not at all satisfied) to 10 (completely satisfied); 2) whether the respondent has thoughts of separation is based on the question 'Over the past 12 months, have you thought about breaking up your relationship?', 'yes' (1) or 'no' (0).

Independent variables are three types of wives' resources compared to the spouse: earnings, education, and occupational status. Wives' relative earnings are measured by the log of the annual earnings (in ppp, corrected for inflation) ${ }^{5}$ of the wife minus the annual earnings of the husband ${ }^{6}$. Wives' relative education is measured as the highest reached educational level in 7 ISCED categories of the wife minus that of the husband. For relative occupational status ISCO codes were converted into ISEI scores and the ISEI of the woman minus that of the man reflects women's relative occupational resources. Occupation is the job in which the spouse spends most of his/her working hours. To be included in the analyses, both spouses needed to be working at the time of interview or to have had a job before they became inactive or unemployed. ${ }^{7}$ We also take women's absolute earnings, household income, average level of education, and average 
occupational level of the couple into account because the level of resources might bias the effects of relative resources.

We further take several variables into account that have been proven to affect divorce: (1) Intensity of search behavior (age at union formation and (premarital) cohabitation); (2) conflict management, dissatisfaction with division of household labor ${ }^{8}$, gender role values; (3) We try to capture some of the socialization processes of the respondent with two measures: a) the educational level of the mother when the respondent was aged 15. This is a proxy for an equal division of labor within the household during childhood, which could relate to norms that are more egalitarian when it comes to houseand carework. In such a household, a feeling of independence would be valued and a higher educated mother probably also teaches her children that bargaining within the couple is a normal thing to do. Moreover, even if such intergenerational transmission of values, attitudes, or norms would not take place, it could be that the mother acted as a role model by showing that a non-traditional, more egalitarian division of intra-household labor is normal (van Putten, 2009); b) an index measuring commitment values of the respondent using four items: 1. Marriage is an outdated institution; 2 . It is all right for an unmarried couple to live together even if they have no interest in marriage; 3. Marriage is a lifetime relationship and should never be ended; 4. It is all right for a couple with an unhappy marriage to get a divorce even if they have children. The answer categories were strongly agree, agree, agree nor disagree, disagree, strongly disagree. Item 3 is recoded to have higher scores corresponding with high marriage commitment $($ Alpha $=0.61)$.

We also controlled for the number of paid working hours ${ }^{9}$, the number of children in the age group 0-6 and 7-17, being born in the country, and a curvilinear effect of union duration (in months). 
Note that we do not control for outsourcing as this is a collider variable; i.e. a variable that is caused both by resources and by relationship quality (see e.g. Whillans et al. (2017)).

The gender empowerment measure (GEM) indicates a country's gender egalitarianism. This index is constructed by the United Nations from four indicators examining the ability to which women can actively participate in economic and political life and take part in decision-making: (1) the percentage of seats held in parliament by women; (2) the percentage of women being administrators and managers; (3) the percentage of professional and technical workers that are women; (4) the share of income earned by women. Higher scores indicate a more gender-egalitarian society (see Table 2). ${ }^{10}$ Belgium in 2009 is the most egalitarian context, whereas Georgia in 1995 is the most traditional one.

[Table 2]

The GINI coefficient measures the degree of variation that the income distribution of a country has. It is the most common measure of income inequality used and assesses the extent to which the distribution among households deviates from a perfectly equal income distribution. Georgia (1998) is the most income unequal society, whereas Belgium (2004) is the most equal one.

[Table 3]

Analytical approach 
We perform separate analyses for men and women (but these are not couples) ${ }^{11}$, doing a country fixed effects OLS regression with dependent variable 'relationship satisfaction' and a logistic regression with dependent variable 'thoughts about separation'.

An important note is that we use union formation years rather than the year of interview as the societal context. Leaving socialization during childhood aside, we assume that it is the context in which the spouses started to form a union that shapes spouses' division of labor in household tasks and also the division of resources. The union formation year is the period in which the majority of couples divide their domestic and paid work and possible negotiation processes based on relative resources will start.

Because the GEM is only available from 1995 onwards, we drop all relationships that started before that year. This leaves us with a sample size of 13,940 men and women (of whom 8,019 have at least one employed spouse in the household and have a valid score on both earnings and occupational status). Even though there are few missing cases on each variable separately, altogether the sample size reduced to 6,959 with listwise deletion of all missing cases. We therefore used multiple imputation (by using five imputations, MI STATA procedure) to fill in the missing values under the assumption that the missingness was not related to the value on each of the missing variables (MAR) ( $\mathrm{N}=10,837$ for relationship satisfaction and $\mathrm{N}=10,780$ for exit thoughts). These results are similar to the results without missing values imputed.

We run models with potential confounding variables and variables that could be either confounders or mediators. Note that for the educational resources models some of the potential confounding variables are less likely to be confounders (e.g., age at union formation, cohabitation), and they are more likely to be mediators instead. We can never be sure about the time order using cross-sectional data, so both models with and without potential confounders are tested. 


\section{Results}

\section{Descriptive Results}

On average, most respondents are very satisfied with their relationship, although there is variation between countries and between men and women. Satisfaction among women is highest in Romania (average score on satisfaction is 8.94) and lowest in Russia (score 8.02), while for men Romania scores highest (score 9.19) and Lithuania lowest (score 8.66). In all countries, men are more satisfied than women are. In Bulgaria, Romania and Georgia, women think the least about breaking up (about 4-5\%), whereas in Russia 25\% have thoughts about breaking up. For the men, the percentages are $1.4-3 \%$ and $14 \%$, respectively. These gender differences are in line with expectations based on Bernard's (1972) theory of 'his' and 'her' marriage, stating that men benefit more from a marriage (in their mental health) than women.

Looking at the independent variables, we observe that in many countries women on average have more resources relative to their spouses than the other way around (not for earnings, but for education and occupational status). ${ }^{12}$ Reasons for this might be twofold: It might have to do with the fact that we are looking at a relatively recent period (recently-formed couples). Alternatively, it may be because we only consider working men and women (as it is necessary to have (had) a job to determine status or earnings). Higher educated women work more often than lower educated women do.

[Table 4] 
Multivariate models: main effects of relative and absolute resources

In Tables 5a and b, we estimate multivariate models for each of the two outcomes. As Table 5a shows, relative resources relate to relationship satisfaction, but overall absolute resources matter more. ${ }^{13}$ Of the absolute resources, all types of resources matter, whereas of the relative resources only relative earnings has a significant association with relationship satisfaction (for women). The maximum effect of relative earnings on women's relationship satisfaction is $\left[-0.004 *(48--85)^{14}=\right]-0.533$, whereas the maximum effect of absolute household income is $[0.141 *(5.06-4.24)=] 1.312$; of absolute education $[0.119 *(3.60--3.32)=] \quad 0.823$; and of absolute occupational status $[0.004 *(45.20--38.88)=]$ 0.336. In other words, the more women earn compared to their spouses, the lower their satisfaction with the relationship. Higher absolute resources (whether they are income, education, or occupational status) go together with more relationship satisfaction for women. The associations between resources and satisfaction for women become weaker once possible confounding or mediating variables are controlled for. Since the time order of these variables is unclear in cross-sectional data, we must be cautious in interpreting the results from the second model. For men, higher educational and financial resources are associated with more relationship satisfaction. The maximum effects are: for household income: 0.650 and for education: 0.623 . We do not find any cross-partner effects of relative resources on relationship satisfaction for men, whichever resources of the wife are considered. For the educational variables, we also ran a simpler model with only being born in the country and the education of the mother as possible confounders included (and no control variables for other resources than education). The effects are somewhat stronger for absolute educational resources compared to the more extended models presented in Table 5a. 
With respect to thoughts about separation (Table 5b), we find some significant associations for both relative and absolute resources for women, but not for men. The more relative earnings she has compared to her spouse, the more thoughts she has about breaking up (maximum effect is 1.065). Also, the more educational resources she has compared to her spouse is associated with more thoughts about breaking up: $\left[0.066^{*}(5.00\right.$ $--5.00)=]$ 0.660. Furthermore, absolute levels of educational and occupational resources are associated with her break-up thoughts: In higher educational and occupational resource couples, she thinks less about breaking up (maximum effects: for education 1.044; for occupational status: -0.673 . Simpler models for educational resources point to similar effects.

Finally, there is an influence of the context. Societies that are more egalitarian have fewer exit thinkers (women) than more traditional societies, which is in line with our expectation that women in more traditional societies are more often forced to 'vote with their feet' than in more egalitarian ones. Also, we find that the more unequal societies are the more women think about exiting their romantic co-residential relationship, but this effect is only significant in Model 1.

[Table 5a, 5b]

\section{Multivariate models: context-specific effects}

In Tables $6 \mathrm{a}$ and $\mathrm{b}$ and $7 \mathrm{a}$ and $\mathrm{b}$, we present the influence of context as a moderator of the relationship between relative resources and our two outcomes. We find cross-level interaction effects on relationship satisfaction mainly for educational resources. If the couple has a higher education, she reports a higher satisfaction in the most traditional context $[(-.153 *-.349+.161)=.214]$, but this association becomes much weaker in more 
gender-egalitarian contexts $[(.386 *-.349+.161)=.026]$ (Table 6a). A similar pattern applies to him: if he is in a couple with higher education, he reports a higher satisfaction in the most traditional context $[\mathrm{b}=.164]$, but this association also becomes much weaker (and even negative) the more gender egalitarian the context is [b=-.041]. We also find significant context moderation effects of the GINI coefficient: Absolute educational and household financial resources are stronger positively associated with women's relationship satisfaction in more income unequal contexts: Both the effects of household income context [from $(-11.81 * .009+.136)=.030$ in equal to $(16.89 * .009+.136)=.288$ in the most unequal society], and a couple's mean educational level [from .080 to .309] are moderated by the GINI. This last cross-level interaction effect is also present for men: [from .044 to .216]. In addition, the higher her educational attainment compared to his, the more she reports a higher satisfaction in the most equal society $[b=.063]$, but this association flattens (with turning point at centered GINI=-2.5 - which is for instance Lithuania in 1997 or 2004), and eventually becomes negative in the most unequal society [b=-.080] (see also Figure 1). This result is robust to whether we also include the GEM as contextual factor in the model.

[Tables 6a, b]

[Figure 1]

Regarding thoughts of breaking up, we only find a moderation of the relationship between relative education and his exit thoughts: The higher she is educated compared to him, the less he reports break up plans in the most income equal context $(b=-.060)$. This association becomes more negative (turns at centered GINI=1 - e.g. Lithuania in 1999) and then increases again $(b=-.232$ in the most unequal context). 
[Tables $7 \mathrm{a}, \mathrm{b}]$

[Figure 2]

\section{Conclusion and discussion}

In this paper, we studied the association between resources and relationship quality. We expected that more relative resources for women would be associated with more power for women. We also expected spill-over and cross-partner effects to occur for men. Moreover, we not only took couple's relative resources into account but also their absolute levels. We looked at earnings, education, and occupational status as resources and scrutinized context-dependent effects on satisfaction with the relationship and thoughts about divorce.

This paper offers several general findings and implications: (1) First and most importantly, taking both the relative and absolute level of resources into account turned out to be a fruitful exercise. For satisfaction with the relationship, absolute resources matter most (positive effect) (for all types of resources for women and for financial and educational resources for men). Also, more absolute educational and occupational resources are related to less break-up plans for women (see also Wiik et al. (2010) for several countries). Hence, consistent with Conger and Elder's (1994) family stress model, it is crucial to consider a couple's absolute resources: spouses are more likely to exhibit warm and supportive behaviors if they are economically secure. In addition, a robust effect we found is that of the couple's educational resources on men's and women's relationship satisfaction, which is in line with the results for most countries of the study 
of Wiik et al. (2010). What is it about education that makes couples more satisfied? We may speculate that having more educational resources can go together with having better interpersonal skills so that communication among higher educated couples is smoother than among lower educated couples. Moreover, we do find that this positive association is weaker the more egalitarian and income-equal the context is. Note that in our models we have taken into account (to some extent) selection into a co-a residential relationship by including the age at union formation.

(2) Furthermore, we found that relative earnings matter negatively for women's relationship satisfaction and relative earnings and education go together with more thoughts about breaking up for women. This result confirms the findings of Bertrand et al. (2015) who also found a relative resources effect in the US context. Thus, women's bargaining power as measured by earnings decreases her relationship quality, which is in line with the relative resources and bargaining theories (Blood \& Wolfe, 1960; Lundberg \& Pollak, 1996). What is not in line with these theories is the lack of presence of crosspartner or spill-over effects of relative resources for men's relationship quality. Apparently, bargaining only is effective for women's relationship quality and does not affect men's relationship satisfaction or break-up thoughts.

(3) Looking at education and occupational status as resources in addition to earnings broadened our perspective on power relationships and its consequences for relationship quality. We saw that relative education mattered for women's and men's exit thoughts, indicating that bargaining power based on educational resources is likely to occur. Bargaining power might even be particularly captured by education and not earnings or occupational status as there is communication involved to get what one prefers. 
In addition, her relative educational resources in the couple affected men and women differently according to the income inequality in a society. Her relative educational level turns out the least harmful in middle-equal contexts (she is most satisfied with her relationship). Perhaps, women living in middle-income contexts are happier with their relationship the more resources they have because they compare themselves with worse off traditional main breadwinner couples. Such a reference group comparison would be less likely in a low GINI country like Sweden with many dual earners and a more equal division of household labour among most Swedish families or with the higher social layers of a high GINI country like the US where outsourcing is the norm (which also creates gender equality within the couple and alleviates women's 'second shift'). Reference group research is still an underexplored avenue in relative resources research, although Greenstein (1996a) already suggested two decades ago to focus on relative deprivation and subjectively perceived inequity within couples rather than objective inequalities only.

For men, we find a similar unexpected result: He thinks the least about breakingup in mid-equal contexts. Here, an explanation might be that at least in the most unequal societies, there might be more intra-couple conflict, because he does not increase his domestic work hours while she violates the traditional division of paid labor by having a relatively higher educational level, an indication that gender trumps resources (see e.g. Bittman, England, Folbre, Sayer, \& Matheson, 2003 for an example of testing the 'gender display' theory (Brines, 1994)). Note, however, that we also controlled for contextual gender norms by including the GEM. It might still be, however, that in unequal societies, we do not capture the impact of traditional individual gender ideologies. Assessment of the influence of gender ideology is another direction of future research that could be 
explored (see e.g. Nitsche \& Grunow, 2018 on the impact of relative resources on the division of child care work in 'egalitarian island' couples).

(4) Our findings also have some consequences for Oppenheimer's (1997) income independence interpretation (only absolute resources provide information about the actual independence of women in a relationship and the more earnings she has, the more likely she will be able to leave a romantic relationship). We did not observe that more female earnings relate to more exit thoughts for her, although in models that only include women's absolute earnings (and not relative ones), we do find this effect. Due to multicollinearity we could not disentangle the absolute from the relative effect in the presented models and this is an important limitation of the measurement of resources via earnings in this study.

(5) Finally, we found contextual (main) effects: We found that the GINI mattered as contextual factor: In more income unequal societies, women think more about breaking up. Most importantly, we also found that women in more traditional societies think more about breaking up than in more egalitarian societies (for men, the effect is in the same direction, but insignificant). Women in traditional societies are perhaps forced to "vote with their feet' if they want to change the intra-household situation. In such societies, bargaining would not work. Of course, the cultural context coincides partly with the policy context and the one on work-life balance in particular. For instance, in Belgium and France, public child care arrangements for 0-3 and 3-6 year olds are more ample than in the Eastern-European countries (OECD, 2006), whereas parental leave in the Westernand Eastern European societies of our GGS sample are on a par with around 104-156 weeks of paid leave around the year 2000. Thus, it could be that not the egalitarian gender role norms in a society, but rather the generous childcare policies that ease combining work and care are explaining women's lower likelihood to think about breaking up. 
Unfortunately, we could not disentangle these effects as there are no country year data available on work-life balance policies, but it is likely that both policy and culture play a role (Pfau-Effinger, 2005).

(6) To conclude, spouses appear to experience differences in power within their romantic relationships and education seems to be an important indicator of this. As long as the context is not egalitarian to some extent and the income inequality is high, educational differences in relationship quality will exist. Policy makers could address this educational inequality between couples for instance by encouraging better work-life balance policies that support more equal gender role norms within society.

\section{References}

Bernard, J. (1972). The future of marriage. New York: Bantam Books.

Bertrand, M., Kamenica, E., \& Pan, J. (2015). Gender identity and relative income within households. Quarterly Journal of Economics(19023), 571-614. doi:doi:10.1093/qje/qjv001

Bittman, M., England, P., Folbre, N., Sayer, L., \& Matheson, G. (2003). When Does Gender Trump Money? Bargaining and Time in Household Work. The American Journal of Sociology, 109(1), 186.

Blood, R. O., \& Wolfe, D. M. (1960). Husbands and Wives: the Dynamics of Married Living. Illinois: The Free Press of Glencoe.

Boertien, D., \& Härkönen, J. (2018). Why does women's education stabilize marriages? The role of marital attraction and barriers to divorce. Demographic Research, 38.

Brennan, R. T., Barnett, R. C., \& Gareis, K. C. (2001). When She Earns More than He Does: A Longitudinal Study of Dual-Earner Couples. Journal of Marriage and Family, 63(1), 168182.

Brines, J. (1994). Economic Dependency, Gender, and the Division of Labor at Home. The American Journal of Sociology, 100(3), 652.

Conger, R. D., \& Elder, G. H. (1994). Families in troubled times: Adapting to change in rural America. New York: Aldine de Gruyter.

Cooke, L. P. (2006). Policy, Preferences, and Patriarchy: The Division of Domestic Labor in East Germany, West Germany, and the United States. Social Politics: International Studies in Gender, State \& Society, 13(1), 117-143. doi:10.1093/sp/jxj005

Dykstra, P. A., \& Poortman, A.-R. (2010). Economic Resources and Remaining Single: Trends Over Time. European Sociological Review, 26(3), 277-290. doi:10.1093/esr/jcp021

Eeckhaut, M. C. W., Van de Putte, B., Gerris, J. R. M., \& Vermulst, A. A. (2013). Analysing the Effect of Educational Differences between Partners: A Methodological/Theoretical Comparison. European Sociological Review, 29(1), 60-73. doi:10.1093/esr/jcr040

England, P., \& Kilbourne, B. (1990). Markets, marriages, and other mates: The problem of power. In R. Friedland \& S. Robertson (Eds.), Beyond the marketplace: Rethinking economy and society. 
Esping-Andersen, G., \& Billari, F. C. (2015). Re-theorizing Family Demographics. Population and Development Review, 41(1), 1-31. doi:10.1111/j.1728-4457.2015.00024.x

Gong, M. (2007). Does Status Inconsistency Matter for Marital Quality? Journal of Family Issues, 28(12), 1582-1610. doi:10.1177/0192513×07300708

Greenstein, T. N. (1996a). Gender Ideology and Perceptions of the Fairness of the Division of Household Labor: Effects on Marital Quality. Social Forces, 74(3), 1029-1042.

Greenstein, T. N. (1996b). Husbands' Participation in Domestic Labor: Interactive Effects of Wives' and Husbands' Gender Ideologies. Journal of Marriage and Family, 58(3), 585595.

Hajdu, G., \& Hajdu, T. (2018). Intra-Couple Income Distribution and Subjective Well-Being: The Moderating Effect of Gender Norms. European Sociological Review, 34(2), 138-156. doi:10.1093/esr/jcy006

Hardie, J. H., Geist, C., \& Lucas, A. (2014). His and Hers: Economic Factors and Relationship Quality in Germany. Journal of Marriage and Family, 76(4), 728-743. doi:10.1111/jomf.12129

Hirschman, A. (1970). Exit, voice, and loyalty. . Cambridge: Harvard University Press.

Hobson, B. (1990). No Exit, No Voice: Women's Economic Dependency and the Welfare State. Acta Sociologica, 33(3), 235-250. doi:10.1177/000169939003300305

Hochschild, A. R., \& Machung, A. (1989). The Second Shift. New York: Viking Penguin.

Huber, J., \& Spitze, G. (1980). Considering Divorce: An Expansion of Becker's Theory of Marital Instability. The American Journal of Sociology, 86(1), 75-89.

Karney, B. R., \& Bradbury, T. N. (1995). The longitudinal course of marital quality and stability: A review of theory, methods, and research. Psychological Bulletin, 118(1), 3-34. doi:10.1037/0033-2909.118.1.3

Lennon, M. C., \& Rosenfield, S. (1994). Relative Fairness and the Division of Housework: The Importance of Options. American Journal of Sociology, 100(2), 506-531.

Lundberg, S., \& Pollak, R. A. (1996). Bargaining and Distribution in Marriage. Journal of Economic Perspectives, 10(4), 139-158. doi:doi: 10.1257/jep.10.4.139

McKeever, M., \& Wolfinger, N. H. (2001). Reexamining the Economic Costs of Marital Disruption for Women. Social Science Quarterly, 82(1), 202-217. doi:doi:10.1111/0038-4941.00018

Nitsche, N., \& Grunow, D. (2018). Do economic resources play a role in bargaining child care in couples? Parental investment in cases of matching and mismatching gender ideologies in Germany. European Societies, 1-31. doi:10.1080/14616696.2018.1473626

Nock, S. (1995). A comparison of marriages and cohabiting relationships. Journal of Family Issues, 16(1), 53-76.

OECD. (2006). OECD Family database. Retrieved from www.oecd.org/els/social/family/database

Oppenheimer, V. K. (1997). Women's Employment and the Gain to Marriage: The Specialization and Trading Model. Annual Review of Sociology, 23, 431.

Pfau-Effinger, B. (2005). Culture and welfare state policies: Reflections on a complex interrelation. Journal of Social Policy, 34(1), 3-20.

Pouwels, B. (2011). Work, family, and happiness: Essays on interdependence within families, life events, and time allocation decisions. Utrecht University, Utrecht.

Rodman, H. (1967). Marital Power in France, Greece, Yugoslavia, and the United States: A Cross-National Discussion. Journal of Marriage and Family, 29(2), 320-324. doi: $10.2307 / 349693$

Rogers, S. J., \& DeBoer, D. D. (2001). Changes in Wives' Income: Effects on Marital Happiness, Psychological Well-Being, and the Risk of Divorce. Journal of Marriage and Family, 63(2), 458-472.

Ruppanner, L. (2010). Cross-national reports of housework: An investigation of the gender empowerment measure. Social Science Research, 39(6), 963-975. doi:http://dx.doi.org/10.1016/j.ssresearch.2010.04.002

Tichenor, V. (2005). Maintaining Men's Dominance: Negotiating Identity and Power When She Earns More. Sex Roles, 53(3), 191-205. doi:10.1007/s11199-005-5678-2

Tynes, S. R. (1990). Educational Heterogamy and Marital Satisfaction between Spouses. Social Science Research, 19, 153-174.

van Berkel, M. (1998). Who dominates when? Assymetrical patterns of influence among Dutch husbands and wives. Katholieke Universiteit Nijmegen, Nijmegen.

van Damme, M. (2010). Vrouwen die hun eigen boontjes doppen. Sociale klasse en het inkomen van Britse, gescheiden vrouwen. Tijdschrift voor Genderstudies, 13(4), 48-61. 
Van den Troost, A., Vermulst, A. A., Gerris, J. R. M., Matthijs, K., \& Welkenhuysen-Gybels, J. (2006). Effects of Spousal Economic and Cultural Factors on Dutch Marital Satisfaction. Journal of Family and Economic Issues, 27(2), 235-262. doi:10.1007/s10834-006-90169

van Putten, A. E. (2009). The role of intergenerational transfers in gendered labour patterns. Universiteit Utrecht, Amsterdam/Den Haag: Aksant/Nederlands Interdisciplinair Demografisch Instituut (NIDI rapport 79)

Vannoy, D., \& Cubbins, L. A. (2001). Relative Socioeconomic Status of Spouses, Gender Attitudes, and Attributes, and Marital Quality Experienced by Couples in Metropolitan Moscow. Journal of Comparative Family Studies, 32(2), 195-217.

West, C., \& Zimmerman, D. H. (1987). Doing Gender. Gender and Society, 1(2), 125-151.

Whillans, A. V., Dunnb, E. W., Smeets, P., Bekkers, R., \& Norton, M. I. (2017). Buying time promotes happiness. PNAS, 114(32), 8523-8527.

Wiik, K. A., Lappegård, T., \& Keizer, R. (2010). Relationship quality in Europe. (633). Statistics Norway, Research Department, Norway.

Zhang, H., Tsang, S. K. M., Peilian, C., Yee Tak, C., Xiulan, Z., \& Yip, P. S. F. (2012). Wives' Relative Income and Marital Satisfaction among the Urban Chinese Population: Exploring Some Moderating Effects. Journal of Comparative Family Studies, 43(2), 185-199. 


\section{Tables}

Table 1. Hypotheses on relationship satisfaction and break up plans for men and women by relative and absolute resources.

\begin{tabular}{|c|c|c|c|c|c|c|}
\hline 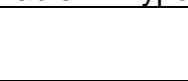 & $\begin{array}{l}\text { Relationship } \\
\text { satisfaction }\end{array}$ & Break up plans & $\begin{array}{l}\text { Relationship satisfaction } \\
{ }^{*} \text { Gender norms }\end{array}$ & $\begin{array}{l}\text { Break up plans* Gender } \\
\text { norms }\end{array}$ & $\begin{array}{l}\text { Relationship satisfaction * } \\
\text { Income inequality }\end{array}$ & $\begin{array}{l}\text { Break up plans* Income } \\
\text { inequality }\end{array}$ \\
\hline $\begin{array}{l}\text { Relative } \\
\text { resources }\end{array}$ & $\begin{array}{l}\text { Women: - (H1a) } \\
\text { Men: - (H1b) }\end{array}$ & $\begin{array}{l}\text { Women: + (H2a) } \\
\text { Men: + (H2b) }\end{array}$ & $\begin{array}{l}\text { Women: - traditional-> + } \\
\text { egalitarian (H1a_norms) } \\
\text { Men: - traditional -> + } \\
\text { egalitarian (H1b_norms) }\end{array}$ & $\begin{array}{l}\text { Women: + traditional-> - } \\
\text { egalitarian (H2a_norms) } \\
\text { Men: + traditional -> - } \\
\text { egalitarian (H2b_norms) }\end{array}$ & $\begin{array}{l}\text { Women: + curvilinear: the } \\
\text { more inequality, } \\
\text { association from - -> + -> - } \\
\text { (H1a_inequality) } \\
\text { Men: + curvilinear: the } \\
\text { more inequality, } \\
\text { association from - ->+ -> - } \\
\text { (H1b_inequality) }\end{array}$ & $\begin{array}{l}\text { Women: - curvilinear: the } \\
\text { more inequality, } \\
\text { association from +->-->+ } \\
\text { (H2a_inequality) } \\
\text { Men: + curvilinear: the } \\
\text { more inequality, } \\
\text { association from +->- ->+ } \\
\text { (H2b_inequality) }\end{array}$ \\
\hline $\begin{array}{l}\text { Absolute } \\
\text { individual } \\
\text { resources }\end{array}$ & $\begin{array}{l}\text { Women: - (H3a) } \\
\text { Men: - (H3b) }\end{array}$ & $\begin{array}{l}\text { Women: + (H4a) } \\
\text { Men: + (H4b) }\end{array}$ & & & & \\
\hline $\begin{array}{l}\text { Absolute } \\
\text { household } \\
\text { resources }\end{array}$ & $\begin{array}{l}\text { Women: + (H5a) } \\
\text { Men: + (H5b) }\end{array}$ & $\begin{array}{l}\text { Women: - (H6a) } \\
\text { Men: - (H6b) }\end{array}$ & & & & \\
\hline
\end{tabular}


Table 2. Gender Empowerment Measure scores for eight countries.

\begin{tabular}{|c|c|c|c|c|c|c|c|c|}
\hline & Bulgaria & Russia & Georgia & France & Romania & Belgium & Lithuania & $\begin{array}{l}\text { Czech } \\
\text { Republic }\end{array}$ \\
\hline 1995 & 0.481 & 0.375 & 0.335 & 0.433 & 0.352 & 0.479 & 0.451 & 0.473 \\
\hline 1996 & 0.486 & 0.385 & 0.340 & 0.437 & 0.368 & 0.580 & 0.460 & 0.486 \\
\hline 1997 & 0.487 & 0.395 & 0.345 & 0.452 & 0.381 & 0.591 & 0.470 & 0.497 \\
\hline 1998 & 0.462 & 0.405 & 0.350 & 0.489 & 0.402 & 0.600 & 0.479 & 0.511 \\
\hline 1999 & 0.457 & 0.415 & 0.355 & 0.499 & 0.400 & 0.610 & 0.517 & 0.524 \\
\hline 2000 & 0.453 & 0.426 & 0.360 & 0.506 & 0.405 & 0.725 & 0.531 & 0.537 \\
\hline 2001 & 0.446 & 0.434 & 0.365 & 0.517 & 0.449 & 0.692 & 0.474 & 0.546 \\
\hline 2002 & 0.439 & 0.450 & 0.370 & 0.535 & 0.450 & 0.706 & 0.483 & 0.560 \\
\hline 2003 & 0.431 & 0.440 & 0.381 & 0.566 & 0.460 & 0.695 & 0.499 & 0.579 \\
\hline 2004 & 0.424 & 0.467 & 0.387 & 0.556 & 0.465 & 0.808 & 0.508 & 0.586 \\
\hline 2005 & & & 0.416 & 0.582 & 0.488 & 0.828 & 0.614 & 0.595 \\
\hline 2006 & & & 0.407 & & & 0.855 & 0.635 & \\
\hline 2007/8 & & & & & & 0.850 & & \\
\hline 2009 & & & & & & 0.874 & 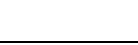 & \\
\hline
\end{tabular}


Table 3. GINI coefficient for eight countries.

\begin{tabular}{|c|c|c|c|c|c|c|c|c|}
\hline & Bulgaria & Russia & Georgia & France & Romania & Belgium & Lithuania & $\begin{array}{l}\text { Czech } \\
\text { Republic }\end{array}$ \\
\hline 1995 & 38.4 & 43.9 & & 29 & 30.6 & 29 & 33.3 & 21.6 \\
\hline 1996 & 35.7 & 50.1 & 37.13 & 29 & 30.2 & 28 & 34.7 & 23 \\
\hline 1997 & 36.6 & 38.41 & 49.8 & 29 & 30.5 & 27 & 30.9 & 23.9 \\
\hline 1998 & 34.5 & 44.6 & 50.3 & 28 & 29.8 & 27 & 33.2 & 25.8 \\
\hline 1999 & 32.6 & 37.44 & 40.15 & 29 & 29.9 & 29 & 34.3 & 23.2 \\
\hline 2000 & 33.2 & 43.2 & 40.48 & 28 & 31 & 30 & 35.5 & 23.1 \\
\hline 2001 & 33.3 & 42.2 & 45.8 & 27 & 35.3 & 28 & 35.4 & 23.7 \\
\hline 2002 & 37 & 49.1 & 45.4 & 27 & 34.9 & & 35.7 & 23.4 \\
\hline 2003 & 35.1 & 40.69 & 39.53 & 27 & 35.2 & 28.3 & 31.8 & 24.6 \\
\hline 2004 & 35.8 & 46.9 & 39.78 & 28.2 & 35.9 & 26.1 & 30.9 & 23.5 \\
\hline 2005 & & & 40.34 & 27.7 & 36.1 & 28 & 36.3 & 25.8 \\
\hline 2006 & & & 39.71 & & & 27.8 & 35 & \\
\hline 2007/8 & & & & & & 26.3 & & \\
\hline 2009 & & & & & & 27.5 & & \\
\hline
\end{tabular}


Table 4. Descriptive statistics of dependent and main independent variables (women or men's reports). Means and percentages (standard deviations in brackets); range; MI

\begin{tabular}{|c|c|c|c|c|c|c|c|c|c|}
\hline & & Bulgaria & Russia & Georgia & France & Romania & Belgium & Lithuania & Czech Republic \\
\hline \multicolumn{10}{|c|}{ Dependent variables } \\
\hline \multicolumn{10}{|c|}{ Relationship satisfaction } \\
\hline & Women & $8.68(1.70)$ & $8.02(2.21)$ & $8.49(1.74)$ & $8.51(1.34)$ & $8.94(1.22)$ & $8.72(1.26)$ & $8.27(1.62)$ & $8.66(1.75)$ \\
\hline & Men & $8.97(1.48)$ & $8.76(1.64)$ & $8.99(1.43)$ & $8.82(1.19)$ & $9.19(1.01)$ & $8.94(1.18)$ & $8.66(1.28)$ & $8.73(1.64)$ \\
\hline \multicolumn{10}{|c|}{ Having thought about breaking up } \\
\hline & Women & 4.59 & 25 & 4.72 & 15 & 4.47 & 14 & 21 & 13 \\
\hline & Men & 1.4 & 14 & 3.0 & 6.4 & 2.0 & 8.7 & 12 & 9.7 \\
\hline \multicolumn{10}{|c|}{ Resources (centered) } \\
\hline \multicolumn{10}{|c|}{ Log relative earnings } \\
\hline & Women & $-12(21)$ & $-16(24)$ & $-25(23)$ & $-9.63(23)$ & $-13(21)$ & $-6.21(19)$ & $-7.68(19)$ & $-14(23)$ \\
\hline & Men & $-0.77(10)$ & $0.27(9.8)$ & $-4.35(12)$ & $1.01(8.9)$ & $-2.64(12)$ & $-0.11(12)$ & $-0.96(12)$ & $-1.31(12)$ \\
\hline \multicolumn{10}{|c|}{ Log female earnings } \\
\hline & Women & $0.09(3.90)$ & $0.39(3.84)$ & $-2.96(2.99)$ & $2.53(3.89)$ & $-0.15(3.98)$ & $2.68(3.84)$ & $1.61(3.81)$ & $0.59(4.27)$ \\
\hline & Men & $1.52(3.56)$ & $3.05(2.60)$ & $0.56(3.66)$ & $4.20(2.70)$ & $1.59(3.66)$ & $3.66(3.53)$ & $2.43(3.71)$ & $2.47(3.78)$ \\
\hline \multicolumn{10}{|c|}{ Log household income } \\
\hline & Women & $-0.15(0.94)$ & $-0.01(0.85)$ & $-0.57(0.92)$ & $0.43(1.15)$ & $1.17(1.01)$ & $2.14(1.04)$ & $1.11(0.91)$ & $-0.90(0.94)$ \\
\hline & Men & $-0.23(1.00)$ & $-0.06(0.87)$ & $-0.65(1.11)$ & $0.59(1.22)$ & $1.24(0.95)$ & $2.31(0.99)$ & $1.05(0.88)$ & $-0.93(0.94)$ \\
\hline \multicolumn{10}{|c|}{ Relative education } \\
\hline & Women & $0.24(0.98)$ & $0.11(1.14)$ & $0.008(1.06)$ & $0.17(1.86)$ & $-0.10(0.84)$ & $0.22(1.35)$ & $0.26(1.08)$ & $0.01(1.09)$ \\
\hline & Men & $0.20(0.93)$ & $0.33(1.16)$ & $-0.06(1.02)$ & $-0.068(1.91)$ & $-0.09(0.80)$ & $0.14(1.32)$ & $0.12(1.02)$ & $-0.08(1.09)$ \\
\hline \multicolumn{10}{|c|}{ Average educational level partners } \\
\hline & Women & $-0.05(1.11)$ & $0.69(0.88)$ & $0.56(0.92)$ & $0.50(1.35)$ & $-0.17(0.95)$ & $0.43(1.19)$ & $0.37(0.88)$ & $0.06(0.93)$ \\
\hline & Men & $-0.28(1.07)$ & $0.67(0.85)$ & $0.45(0.95)$ & $0.38(1.34)$ & $-0.23(1.01)$ & $0.43(1.18)$ & $0.36(0.89)$ & $0.01(0.94)$ \\
\hline \multicolumn{10}{|c|}{ Relative occupational status } \\
\hline & Women & $0.68(15)$ & $3.86(18)$ & $3.85(17)$ & $0.81(15)$ & $0.65(13)$ & $1.14(17)$ & $2.66(18)$ & $0.28(16)$ \\
\hline & Men & $2.05(15)$ & $2.28(19)$ & $4.21(17)$ & $0.43(16)$ & $1.65(13)$ & $-0.21(17)$ & $1.20(17)$ & $-1.48(15)$ \\
\hline \multicolumn{10}{|c|}{ Average occupational status partners } \\
\hline & Women & $0.43(11)$ & $0.87(12)$ & $0.66(12)$ & $2.62(12)$ & $-2.42(13)$ & $5.84(12)$ & $1.52(13)$ & $1.66(11)$ \\
\hline & Men & $-0.94(10)$ & $-0.325(12)$ & $0.39(13)$ & $2.65(12)$ & $-3.11(12)$ & $5.99(12)$ & $2.75(13)$ & $0.29(11)$ \\
\hline \multirow[t]{2}{*}{$\mathrm{N}$} & Women & 959 & 862 & 614 & 835 & 716 & 885 & 595 & 638 \\
\hline & Men & 760 & 648 & 461 & 638 & 855 & 758 & 793 & 699 \\
\hline
\end{tabular}

${ }^{a}$ For France, Romania, and Belgium, only the first two digits of the ISCO codes were available 
Table 5a. Country fixed effects OLS regression of relationship satisfaction (women's and men's reports).

\begin{tabular}{|c|c|c|c|c|}
\hline & Women & & Men & \\
\hline & M1 & M2 & M1 & M2 \\
\hline Log relative earnings (centered) & $-0.004^{\star}$ & $-0.003^{* *}$ & -0.003 & -0.000 \\
\hline Log female earnings (centered) & -0.007 & 0.000 & 0.013 & 0.003 \\
\hline Log household income (centered) & $0.141^{* * *}$ & $0.072^{* \star}$ & $0.061^{* *}$ & 0.016 \\
\hline Relative education (centered) & -0.033 & -0.016 & 0.004 & 0.008 \\
\hline Mean education (centered) & $0.119^{* * *}$ & $0.062^{* *}$ & $0.087^{\star * *}$ & $0.049^{*}$ \\
\hline Relative occupational status (centered) & -0.001 & -0.000 & -0.001 & -0.001 \\
\hline Mean occupational status (centered) & $0.004^{*}$ & 0.002 & -0.001 & -0.000 \\
\hline Age at union formation & $-0.012^{* * *}$ & $-0.013^{* * *}$ & -0.001 & -0.001 \\
\hline Union duration & $-0.011^{* * *}$ & $-0.007^{* * *}$ & $-0.005^{\star *}$ & $-0.004^{* *}$ \\
\hline Union duration^2 & $0.000^{\star * *}$ & $0.000^{\star * *}$ & $0.000^{* *}$ & $0.000^{*}$ \\
\hline (Premarital) cohabitation & -0.075 & 0.063 & $-0.113^{* *}$ & -0.012 \\
\hline Number of children under 6 years & -0.041 & 0.035 & -0.013 & 0.027 \\
\hline Number of children 7-17 years & $-0.171^{\star \star \star}$ & $-0.074^{\star *}$ & $-0.089^{* *}$ & $-0.053^{*}$ \\
\hline Education of mother when age 15 & 0.001 & -0.010 & $0.049^{* *}$ & 0.021 \\
\hline Native & $0.213^{*}$ & 0.117 & -0.093 & 0.005 \\
\hline Bad conflict management & & $-0.178^{\star \star *}$ & & $-0.154^{\star * *}$ \\
\hline Being unsatisfied with division of labor & & $-0.439^{\star * *}$ & & $-0.404^{\star \star \star}$ \\
\hline Egalitarian gender role values & & $0.115^{\star * *}$ & & $0.062^{*}$ \\
\hline Number of working hours & & 0.001 & & 0.002 \\
\hline Commitment values & & $0.178^{\star * *}$ & & $0.155^{\star \star *}$ \\
\hline Country fixed effects & YES & YES & YES & YES \\
\hline GEM (centered) & 0.340 & 0.094 & 0.265 & -0.078 \\
\hline GINI (centered) & -0.007 & -0.007 & -0.001 & -0.006 \\
\hline Constant & $9.336^{* * *}$ & $9.195^{\star \star *}$ & $9.262^{* * *}$ & $8.827^{\star \star *}$ \\
\hline $\mathrm{N}$ & 5602 & 5602 & 5235 & 5235 \\
\hline
\end{tabular}

${ }^{*} p<0.05,{ }^{* *} p<0.01,{ }^{* * *} p<0.001$, one-tailed tested; standard errors GEM and GINI coefficients are clustered on the country level 
Table 5b. Country fixed effects logistic regression of thoughts about breaking up (women's and men's reports).

\begin{tabular}{|c|c|c|c|c|}
\hline & Women & & Men & \\
\hline & M1 & M2 & M1 & M2 \\
\hline Log relative earnings (centered) & $0.008^{*}$ & 0.008 & 0.002 & 0.001 \\
\hline Log female earnings (centered) & 0.001 & 0.030 & -0.031 & -0.030 \\
\hline Log household income (centered) & -0.009 & 0.063 & 0.006 & 0.035 \\
\hline Relative education (centered) & $0.066^{*}$ & $0.067^{\star}$ & 0.030 & 0.022 \\
\hline Mean education (centered) & $-0.151^{* *}$ & -0.078 & -0.054 & 0.009 \\
\hline Relative occupational status (centered) & 0.003 & 0.002 & 0.001 & 0.002 \\
\hline Mean occupational status (centered) & $-0.008^{*}$ & -0.003 & 0.008 & 0.010 \\
\hline Age at union formation & $0.010^{*}$ & $0.015^{\star \star}$ & -0.007 & -0.007 \\
\hline Union duration & 0.006 & 0.000 & 0.001 & -0.000 \\
\hline Union duration^2 & $-0.000^{* *}$ & -0.000 & -0.000 & -0.000 \\
\hline (Premarital) cohabitation & $0.562^{\star \star *}$ & $0.396^{\star \star \star}$ & $0.623^{\star * *}$ & $0.445^{\star *}$ \\
\hline Number of children under 6 years & $-0.228^{\star *}$ & $-0.286^{\star * *}$ & $-0.197^{*}$ & $-0.267^{\star *}$ \\
\hline Number of children $7-17$ years & $0.228^{\star \star \star}$ & 0.100 & 0.124 & 0.108 \\
\hline Education of mother when age 15 & $0.145^{\star \star \star}$ & $0.158^{\star \star \star}$ & 0.004 & 0.016 \\
\hline Native & $-0.296^{*}$ & -0.291 & -0.201 & -0.263 \\
\hline Bad conflict management & & $0.381^{* * *}$ & & $0.317^{\star \star \star}$ \\
\hline Being unsatisfied with division of labor & & $0.259^{\star \star *}$ & & $0.197^{\star \star \star}$ \\
\hline Egalitarian gender role values & & -0.037 & & 0.025 \\
\hline Number of working hours & & $-0.011^{* * *}$ & & -0.000 \\
\hline Commitment values & & $-0.415^{\star \star \star}$ & & $-0.260^{\star *}$ \\
\hline Country fixed effects & YES & YES & YES & YES \\
\hline GEM (centered) & $-2.320^{\star * *}$ & $-1.883^{\star * \star}$ & -1.914 & -1.454 \\
\hline GINI (centered) & $0.016^{\star \star}$ & 0.013 & 0.005 & 0.014 \\
\hline Constant & $-3.876^{\star \star \star}$ & $-3.907^{\star \star \star}$ & $-4.414^{\star * \star}$ & $-4.189^{\star \star \star}$ \\
\hline $\mathrm{N}$ & 5592 & 5592 & 5188 & 5188 \\
\hline
\end{tabular}

${ }^{*} p<0.05,{ }^{* *} p<0.01,{ }^{* * *} p<0.001$, one-tailed tested; standard errors GEM and GINI coefficients are clustered on the country level 
Table 6a. Country fixed effects OLS regression of relationship satisfaction (women's and men's reports). Interactions of resourcesGEM. All variables are centered. Models 1 (without mediating variables)

\begin{tabular}{|c|c|c|c|c|c|c|}
\hline & Women & Men & Women & Men & Women & Men \\
\hline Log relative earnings & $-0.003^{*}$ & -0.003 & & & $-0.003^{\star}$ & -0.003 \\
\hline Log female earnings & -0.007 & $0.013^{*}$ & & & -0.006 & 0.012 \\
\hline Log household income & $0.144^{* * *}$ & $0.059^{* *}$ & & & $0.142^{* \star *}$ & $0.061^{* *}$ \\
\hline Relative education & -0.031 & 0.004 & $-0.040^{*}$ & -0.005 & -0.032 & 0.004 \\
\hline Mean education & $0.121^{\star * *}$ & $0.089^{\star * *}$ & $0.161^{\star * *}$ & $0.106^{\star * *}$ & $0.122^{\star * *}$ & $0.090^{* * *}$ \\
\hline Relative occupational status & -0.001 & -0.001 & & & -0.001 & -0.001 \\
\hline Mean occupational status & $0.004^{*}$ & -0.001 & & & $0.004^{*}$ & -0.001 \\
\hline GEM & 0.979 & 0.327 & $1.469^{\star \star *}$ & $0.644^{*}$ & 0.369 & 0.385 \\
\hline GINI & -0.007 & -0.001 & -0.007 & 0.001 & -0.007 & -0.001 \\
\hline Relative earnings ${ }^{\star} G E M$ & 0.017 & -0.006 & & & & \\
\hline Female earnings ${ }^{*} G E M$ & -0.056 & -0.090 & & & & \\
\hline Household income*GEM & -0.234 & 0.136 & & & & \\
\hline Relative education*GEM & & & 0.169 & 0.215 & & \\
\hline Mean education*GEM & & & $-0.349^{*}$ & $-0.381^{* *}$ & & \\
\hline Relative occupational status*GEM & & & & & 0.004 & -0.005 \\
\hline Mean occupational status ${ }^{\star}$ GEM & & & & & -0.007 & -0.021 \\
\hline Controlled for confounders ${ }^{\mathrm{a}}$ & YES & YES & SOME & SOME & YES & YES \\
\hline $\mathrm{N}$ & 5602 & 5235 & 5679 & 5365 & 5602 & 5235 \\
\hline
\end{tabular}

${ }^{a}$ For the models with education as effects of interest, certain confounders are rather mediators. Therefore, we did not control for that many variables as for the earnings and occupational status models (we only included education of the mother and being born in the country as possible confounders in the initial educational models).

${ }^{\star} p<0.05,{ }^{* *} p<0.01,{ }^{* * *} p<0.001$, one-tailed tested 
Table 6b. Country fixed effects OLS regression of relationship satisfaction (women's and men's reports). Interactions of resources ${ }^{\star} \mathrm{GINI}$. All variables are centered. Models 1 (without mediating variables)

\begin{tabular}{|c|c|c|c|c|c|c|}
\hline & Women & Men & Women & Men & Women & Men \\
\hline Log relative earnings & -0.001 & -0.002 & & & $-0.003^{*}$ & -0.003 \\
\hline Log female earnings & -0.007 & 0.013 & & & -0.006 & 0.012 \\
\hline Log household income & $0.136^{* * *}$ & 0.032 & & & $0.142^{\star \star *}$ & $0.061^{* *}$ \\
\hline Relative education & -0.031 & 0.004 & 0.004 & 0.015 & -0.031 & 0.005 \\
\hline Mean education & $0.119^{* * *}$ & $0.090^{* * *}$ & $0.174^{* * *}$ & $0.115^{\star * *}$ & $0.125^{\star * *}$ & $0.091^{* * *}$ \\
\hline Relative occupational status & -0.001 & -0.001 & & & -0.001 & -0.001 \\
\hline Mean occupational status & $0.004^{*}$ & -0.001 & & & $0.005^{*}$ & -0.003 \\
\hline GEM & 0.366 & 0.244 & $1.417^{\star \star *}$ & $0.588^{*}$ & 0.372 & 0.288 \\
\hline GINI & -0.016 & -0.000 & -0.008 & 0.001 & -0.007 & -0.001 \\
\hline Relative earnings ${ }^{*} \mathrm{GINI}$ & 0.000 & 0.000 & & & & \\
\hline Relative earnings ${ }^{\star} \mathrm{GINI}^{\wedge} 2$ & -0.000 & -0.000 & & & & \\
\hline Female earnings ${ }^{\star} \mathrm{GINI}$ & -0.001 & 0.001 & & & & \\
\hline Female earnings $\left.{ }^{\star} \mathrm{GINI}\right|^{\wedge} 2$ & -0.000 & 0.000 & & & & \\
\hline Household income* GINI & $0.009^{*}$ & -0.005 & & & & \\
\hline Household income*GINI^2 & 0.000 & 0.001 & & & & \\
\hline Relative education* ${ }^{*} \mathrm{INI}$ & & & -0.005 & -0.002 & & \\
\hline Relative education*GINI^2 & & & $-0.001^{* *}$ & -0.000 & & \\
\hline Mean education*GINI & & & $0.008^{* *}$ & $0.006^{*}$ & & \\
\hline Mean education*GINI^2 & & & -0.000 & -0.000 & & \\
\hline Relative occupational status ${ }^{*} \mathrm{GINI}$ & & & & & 0.000 & 0.000 \\
\hline Relative occupational status* ${ }^{\star} I_{N} I^{\wedge} 2$ & & & & & -0.000 & -0.000 \\
\hline Mean occupational status* GINI & & & & & 0.000 & 0.000 \\
\hline Mean occupational status ${ }^{*} \mathrm{GINI}{ }^{\wedge} 2$ & & & & & -0.000 & 0.000 \\
\hline Controlled for confounders ${ }^{a}$ & YES & YES & SOME & SOME & YES & YES \\
\hline $\mathrm{N}$ & 5602 & 5235 & 5679 & 5365 & 5602 & 5235 \\
\hline
\end{tabular}

${ }^{a}$ For the models with education as effects of interest, certain confounders are rather mediators. Therefore, we did not control for that many variables as for the earnings and occupational status models (we only included education of the mother and being born in the country as possible confounders in the initial educational models).

${ }_{*} p<0.05,{ }^{* *} p<0.01, * * * 0<0.001$, one-tailed tested 
Table 7a. Country fixed effects OLS regression of breaking up plans (women's and men's reports). Interactions of resources*GEM. All variables are centered. Models 1 (without mediating variables)

\begin{tabular}{|c|c|c|c|c|c|c|}
\hline & Women & Men & Women & Men & Women & Men \\
\hline Log relative earnings & $0.009^{*}$ & 0.003 & & & $0.008^{*}$ & 0.002 \\
\hline Log female earnings & -0.000 & $-0.040^{*}$ & & & 0.002 & -0.032 \\
\hline Log household income & -0.008 & 0.030 & & & -0.011 & 0.008 \\
\hline Relative education & $0.064^{*}$ & 0.033 & $0.076^{*}$ & 0.038 & $0.063^{*}$ & 0.028 \\
\hline Mean education & $-0.156^{\star *}$ & -0.057 & $-0.169^{\star * *}$ & -0.058 & $-0.153^{\star *}$ & -0.060 \\
\hline Relative occupational status & 0.003 & 0.001 & & & 0.002 & 0.001 \\
\hline Mean occupational status & $-0.007^{\star}$ & 0.009 & & & -0.007 & 0.008 \\
\hline GEM & $-2.744^{*}$ & -1.613 & $1.582^{*}$ & 1.566 & $-2.261^{*}$ & -2.436 \\
\hline GINI & 0.015 & 0.003 & 0.008 & -0.001 & 0.014 & 0.005 \\
\hline Relative earnings ${ }^{\star} \mathrm{GEM}$ & -0.030 & -0.022 & & & & \\
\hline Female earnings ${ }^{\star} G E M$ & 0.123 & 0.238 & & & & \\
\hline Household income*GEM & -0.007 & -0.566 & & & & \\
\hline Relative education*GEM & & & 0.074 & -0.167 & & \\
\hline Mean education*GEM & & & -0.363 & 0.411 & & \\
\hline Relative occupational status ${ }^{\star}$ GEM & & & & & 0.008 & 0.045 \\
\hline Mean occupational status* ${ }^{*}$ EM & & & & & -0.025 & 0.043 \\
\hline Controlled for confounders $^{\mathrm{a}}$ & YES & YES & SOME & SOME & YES & YES \\
\hline $\mathrm{N}$ & 5592 & 5188 & 5614 & 5200 & 5592 & 5188 \\
\hline
\end{tabular}

${ }^{a}$ For the models with education as effects of interest, certain confounders are rather mediators. Therefore, we did not control for that many variables as for the earnings and occupational status models (we only included education of the mother and being born in the country as possible confounders in the initial educational models).

${ }^{*} p<0.05,{ }^{* *} p<0.01,{ }^{* * *} p<0.001$, one-tailed tested 
Table 7b. Country fixed effects OLS regression of breaking up plans (women's and men's reports). Interactions of resources* ${ }^{*}$ INI. All variables are centered. Models 1 (without mediating variables)

\begin{tabular}{|c|c|c|c|c|c|c|}
\hline & Women & Men & Women & Men & Women & Men \\
\hline Log relative earnings & 0.007 & -0.004 & & & $0.008^{*}$ & 0.002 \\
\hline Log female earnings & -0.008 & -0.044 & & & 0.003 & -0.031 \\
\hline Log household income & 0.028 & 0.028 & & & -0.010 & 0.004 \\
\hline Relative education & $0.064^{*}$ & 0.032 & $0.112^{*}$ & $-0.131^{*}$ & $0.064^{*}$ & 0.032 \\
\hline Mean education & $-0.152^{* *}$ & -0.050 & $-0.153^{\star *}$ & -0.077 & $-0.154^{\star *}$ & -0.054 \\
\hline Relative occupational status & 0.003 & 0.001 & & & -0.000 & 0.001 \\
\hline Mean occupational status & $-0.008^{*}$ & 0.009 & & & -0.009 & 0.007 \\
\hline GEM & $-2.293^{*}$ & -2.070 & $1.544^{*}$ & $1.673^{*}$ & $-2.348^{*}$ & -2.050 \\
\hline GINI & 0.012 & -0.011 & 0.008 & -0.019 & 0.012 & 0.004 \\
\hline Relative earnings ${ }^{*} \mathrm{GINI}$ & 0.000 & -0.001 & & & & \\
\hline Relative earnings ${ }^{\star} \mathrm{GINI}^{\wedge} 2$ & 0.000 & 0.000 & & & & \\
\hline Female earnings ${ }^{*} \mathrm{GINI}$ & 0.001 & 0.000 & & & & \\
\hline Female earnings ${ }^{*} \mathrm{GINI}^{\wedge} 2$ & 0.000 & 0.000 & & & & \\
\hline Household income*GINI & 0.000 & 0.014 & & & & \\
\hline Household income* ${ }^{\star} \mathrm{GINI}{ }^{\wedge} 2$ & -0.001 & -0.000 & & & & \\
\hline Relative education*GINI & & & 0.007 & -0.006 & & \\
\hline Relative education ${ }^{\star} G \mid N I^{\wedge} 2$ & & & -0.000 & $0.003^{* *}$ & & \\
\hline Mean education*GINI & & & 0.009 & -0.007 & & \\
\hline Mean education ${ }^{\star} \mathrm{GINI}{ }^{\wedge} 2$ & & & -0.000 & 0.001 & & \\
\hline Relative occupational status ${ }^{*} \mathrm{GINI}$ & & & & & -0.000 & -0.000 \\
\hline Relative occupational status ${ }^{\star} G \mid N I^{\wedge} 2$ & & & & & 0.000 & 0.000 \\
\hline Mean occupational status ${ }^{*} \mathrm{GINI}$ & & & & & 0.000 & -0.000 \\
\hline Mean occupational status ${ }^{*} \mathrm{GINI}{ }^{\wedge} 2$ & & & & & 0.000 & 0.000 \\
\hline Controlled for confounders ${ }^{a}$ & YES & YES & SOME & SOME & YES & YES \\
\hline $\mathrm{N}$ & 5592 & 5188 & - & 5200 & 55 & - \\
\hline
\end{tabular}

${ }^{a}$ For the models with education as effects of interest, certain confounders are rather mediators. Therefore, we did not control for that many variables as for the earnings and occupational status models (we only included education of the mother and being born in the country as possible confounders in the initial educational models).

${ }_{*} p<0.05, * * p<0.01, * * * 0<0.001$, one-tailed tested 


\section{Figures}

Figure 1. Cross-level curvilinear interaction effect of GINI with relative education on women's relationship satisfaction

\section{GINI}

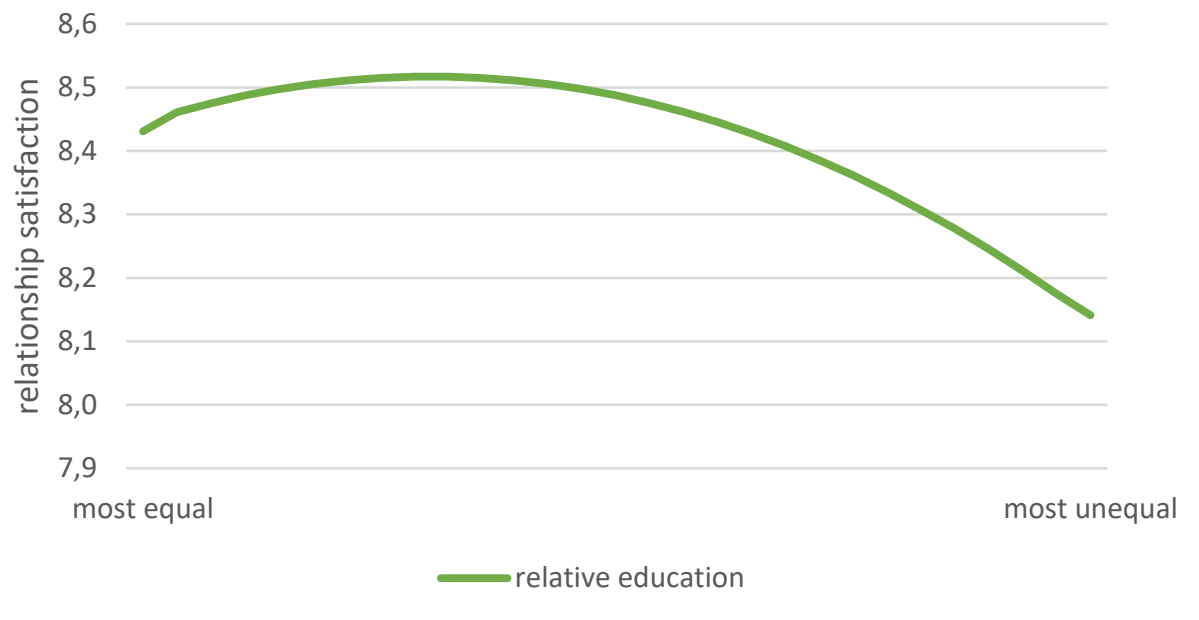

Figure 2. Cross-level curvilinear interaction effect of GINI with relative education on men's break up plans

\section{GINI}

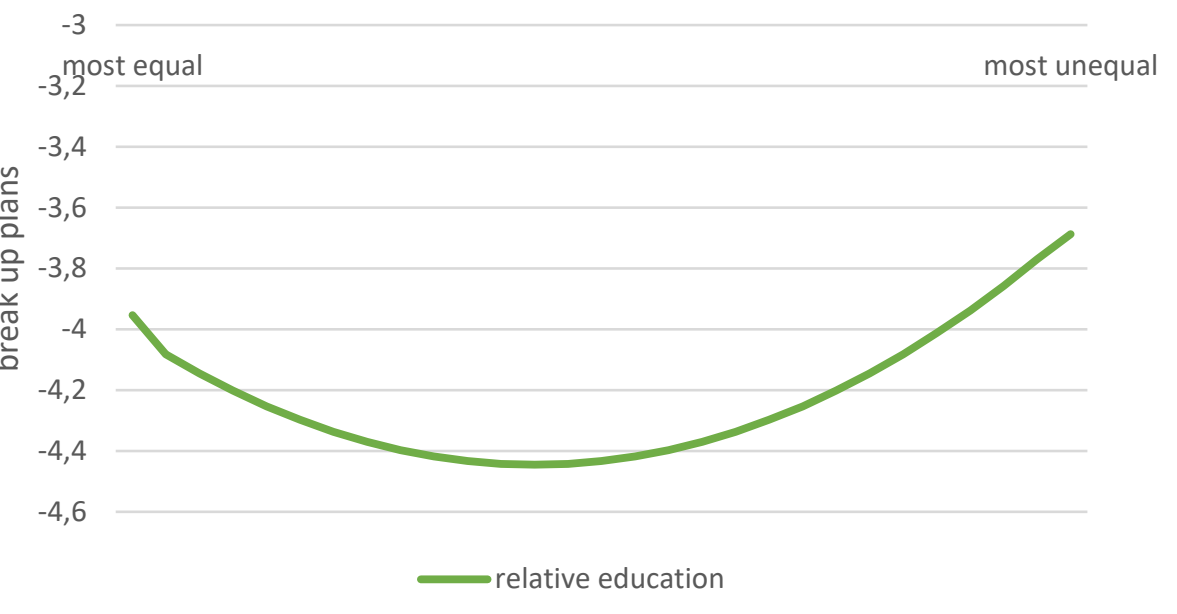




\section{Notes}

1 We are aware of the disadvantages of using cross-sectional data for investigating causal relationships, but since research in this field is still scarce, even cross-sectional data brings us an important step forward.

${ }^{2}$ Note that the study of Huber and Spitze (1980) did not consider absolute earnings when looking at the effect of relative earnings.

${ }^{3}$ Referred to as external 'threat point' in the economic literature.

${ }^{4}$ Note that also individual level gender role beliefs could influence partner's negotiations. We checked interactions of relative resources with individual level gender role values, but found no significant effects.

${ }^{5}$ Cross-national comparability of both spouses' earnings was done by Joanne Muller (Earnings File (W1) provided on http://www.ggp-i.org/data, retrieved April 13, 2017).

${ }^{6}$ We take the natural logarithm of wife's relative earnings to transform the right skewed distribution into a normally distributed one.

7 To check whether this sample selection affects our results, we also included a human capital measure instead of earnings (Sullivan and Gershuny, 2016). This did not substantially change the results so we present here only the results using earnings.

${ }^{8}$ We do not include the division of household labor itself, since this is a collider variable.

9 In many countries, women working more hours have been found to be more likely to break up (Van Damme and Kalmijn, 2014). We do not expect to find a relationship for men though but include the variable anyway for consistency among the models.

${ }^{10}$ As a sensitivity check, we ran models with aggregated gender role values (from GGS) instead of GEM as a macro-indicator of the degree of gender egalitarianism in a country. We did not find any significant effect of this aggregated measure as a main effect. With respect to the interactions with resources, we find weaker effects than when including GEM. Note that a macro-indicator from another source would be a more reliable measure than this aggregated measure of GGS on values. Unfortunately, in other data sources there is no other time-varying measure of gender egalitarianism available.

${ }_{11}$ Note that there can be gender bias in men's and women's reporting of the same variable (Doorten, 2008).

${ }^{12}$ Notice the gender bias in reporting. Men report more often that they are higher educated than women.

${ }^{13}$ Note that the correlation between relative earnings and absolute individual earnings for women is rather high (around 0.75 for women). Such high correlations make it difficult to disentangle relative from absolute resources effects for earnings. Therefore, we also ran all models with relative earnings only included (minor changes in the coefficients). Associations between absolute and relative levels of education and occupational status are very low and thus can be distinguished from one another.

${ }^{14}$ Between brackets is the range of the variable. 